\title{
F3/F11 Cell Surface Molecule Expression in the Developing Mouse Cerebellum Is Polarized at Synaptic Sites and within Granule Cells
}

\author{
C. Faivre-Sarrailh, ${ }^{1}$ G. Gennarini, ${ }^{2}$ C. Goridis, ${ }^{2}$ and G. Rougon ${ }^{1}$ \\ 'Laboratoire de la Différenciation Cellulaire, URA CNRS 179, Faculté des Sciences de Luminy, and ${ }^{2}$ Centre d'Immunologie \\ INSERM-CNRS de Marseille-Luminy, F-13288 Marseille Cedex 9, France
}

\begin{abstract}
The distribution of the F3/F11 neuronal cell surface molecule was investigated in the developing and adult mouse cerebellum by immunocytochemistry at the light and electron microscopic levels. F3/F11 was confined to subsets of neuronal types, since the Purkinje cell body and dendritic arborization as well as the stellate cells were not immunoreactive. In the young developing cerebellum, the granule cell axons strongly express $\mathrm{F} 3 / \mathrm{F} 11$ as soon as they begin to grow, consistent with a functional role in promoting directional outgrowth of neuronal processes. In 10-d-old and adult cerebella, the granule cell bodies and dendrites were not immunoreactive whereas the parallel fibers, which are the granule cell axons, were labeled including in their presynaptic varicosities. By contrast, dendrites, cell bodies, and axons of Golgi cells were labeled by anti-F3 antibodies. Hence, F3/F11 can either be expressed throughout the cell or be polarized to the axons. This raises the question of how segregation of the glypiated F3/F11 molecule between different subcellular compartments depending on the type of neuron is achieved.
\end{abstract}

F3/F11 was found to be present at three types of synaptic sites, suggesting that it might play a role in the formation and maintenance of synapses. However, in each type of synpase, F3/F11 was present at only the pre- or postsynaptic site, never at both: the parallel fiber varicosities contained F3/F11 whereas the postsynaptic compartment in contact, that is, the Purkinje cell dendritic spines, did not. The granule cell dendrites were unlabeled while the mossy fiber terminals contacting them were immunoreactive, and finally, the Golgi cell dendrites and dendritic spines were labeled while the presynaptic compartment contacting them was not. If $F 3 / F 11$ functions as an adhesion molecule in vivo as indicated by in vitro assays, F3/F11-mediated adhesion is likely to be heterophilic.

During neuroontogeny, cell-cell adhesion molecules have been shown to play important roles in a diverse set of processes that include the migration of neuroblasts, neurite outgrowth and fasciculation, axonal guidance to the target cell (for reviews, see

\footnotetext{
Received Apr. 10, 1991; revised Aug. 26, 1991; accepted Aug. 28, 1991.

This work was supported by an institutional grant from the CNRS and by grants from the Association Recherche coutre le Cancer, the Association Française coutre les Myopathics, and the Communaule Economique Europeene to G.R. We are indebted to $\mathrm{G}$. Monti for expert technical assistance.

Correspondence should be addressed to C. Faivre-Sarrailh, Laboratoire de la Differenciation Cellulaire - URA 179, Faculté des Sciences de Luminy - Case 901, F-13288 Marseille Cedex 9, France.
}

Copyright (C) 1992 Society for Neuroscience $0270-6474 / 92 / 120257-11 \$ 05.00 / 0$
Edelman, 1986; Rutishauser and Jessel, 1988; Doherty and Walsh, 1989), and the establishment of a functional synapse (Chow, 1990). In the adult, maintenance and reshuffling of synapses depend on interactions between pre- and postsynaptic structures that are likely to bc fostcred not only by the exchange of diffusible molecules, but also by adhesive interactions mediated by compatible cell surface ligands. Most proven or suspected cell-cell adhesion molecules identified to date in the nervous system belong to the Ig superfamily (Williams and Barclay, 1988), and their relative diversity could enable them to determine the appropriate neuron-neuron connections. They include proteins with rather ubiquitous cellular distribution such as N-CAM, which has been proposed to play a general permissive role in adhesion (Edelman, 1984; Rutishauser and Jessel, 1988), and molecules whose expression in the nervous system is restricted to subsets of neurons and/or to the axonal compartment within a given neuron, such as L1 (Persohn and Schachner, 1987; Moos et al., 1988), TAG-1 (Dodd et al., 1988; Furley et al., 1990), F11 (Brümmendorf et al., 1989), F3 (Gennarini et al., 1989a), and Thyl (Morris et al., 1985; see He et al., 1991, for its status as an adhesion molecule). They may be transmembrane proteins (N-CAM, L1) or be anchored to the surface membrane via a glycosyl phosphatidylinositol (GPI) linkage (TAG-1, F11, F3, Thy1). A comprehensive description of the precise cellular and subcellular localization of these molecules during development forms a useful baseline for understanding the functional roles that can be attributed to the neuronally expressed members of the Ig superfamily.

We have been studying the mouse $F 3$ protein, which displays high sequence homology with chicken F11 (77\% sequence identity at the amino acid level). They can thus be considered as species homologs, and we will henceforth use the term of F3/ F11. This protein contains six Ig domains of the C2 type (Williams and Barclay, 1988), a premembrane region with sequence similarity to fibronectin type III repeats, and a GPI membrane anchor (Gennarini et al., 1989b). It also bears the L2/HNK1 carbohydrate epitope that is likely to be involved in adhesion (Keilhauer et al., 1985; Riopelle et al., 1986; Künemund et al., 1988). Moreover, recent experiments on F3/F11-transfected CHO cells indicate that this molecule mediates intercellular adhesion (Gennarini et al., 1991). F3/F11 is expressed in the brain at the time of differentiation (Gennarini et al., 1990) and has been shown to promote in vitro neurite outgrowth (Chang et al., 1987; Gennarini et al., 1991). Taken logether, these observations indicate that this molecule may be actively involved in neural morphogenesis. In the present study, the distribution of the F3/F11 cell surface molecule was investigated at the elec- 

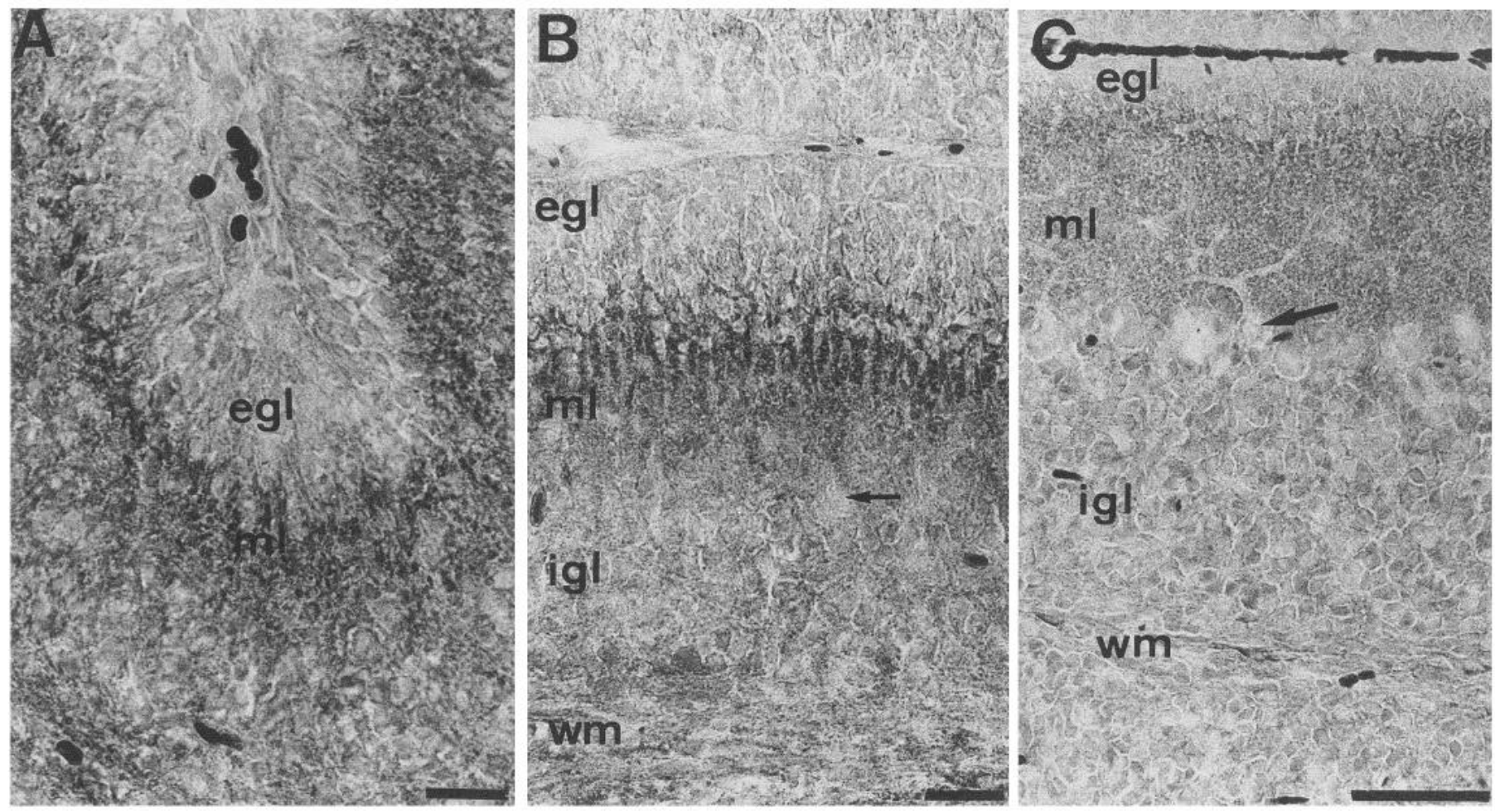

Figure 1. Immunocytochemical localization of F3/F11 in the cerebellum of mice aged $1(A), 5(B)$, and $10 \mathrm{~d}(C)$. External granular layer $(e g l)$ molecular layer $(\mathrm{ml})$, internal granular layer $(\mathrm{igl})$, and white matter $(w m)$ are shown. Purkinje cell bodies are indicated with arrow, and granule cell bodies are not immunoreactive. A punctate staining pattern in the molecular layer, corresponding to the parallel fibers, began to appear in the newborn cerebellum. Scale bar, $50 \mu \mathrm{m}$.

tron microscopic level in the developing and adult cerebellar cortex of the mouse. This structure is known to be formed by identifiable neuronal types that establish relatively simple circuitry and connections (Palay and Chan-Palay, 1974). Moreover, the development of the cerebellum is mainly postnatal and provides an opportunity to study various steps of ontogenesis-migration, dendritic and axonal outgrowth, synaptogenesis - that have been extensively described (Altman, 1972a,b).

\section{Materials and Methods}

\section{Materials}

All chemicals, unless otherwise indicated, were from Merck (Darmstadt, Germany) or Sigma (Paris, France). Glutaraldehyde was purchased from Ladd (Burlington, VT). The anti-rabbit $\gamma$-globulin Fab peroxidase was from Biosys (Compiègne, France). Two different antisera giving similar results have been used. One designated anti-F3 serum was raised against gel-purified F3 glycoprotein. In mouse brain extracts, this serum recognizes a $135 \mathrm{kDa}$ polypeptide (Gennarini et al., 1990b). The $135 \mathrm{kDa}$ molecule can be precipitated from surface-iodinated cerebellar cells, thus demonstrating its expression on the cell surface of neurons (Gennarini et al., 1989a). The other one, designated anti-D1-1 serum, was prepared by immunizing rabbits with the $\beta$-galactosidase fusion protein encoded by the 280 base pair clone D1-1. In immunoblots of mouse brain extracts, anti-D1-1 serum reveals a major $135 \mathrm{kDa}$ and a minor $90 \mathrm{kDa}$ band. The latter chain is probably a breakdown product (Gennarini et al., 1989a).

\section{Immunocytochemistry}

Light microscopy. Mice 1, 5, and $10 \mathrm{~d}$ of age were killed by decapitation or intracardiac perfusion. Their cerebella were cut out; immersed overnight in the fixative composed of $4 \%$ paraformaldehyde, $0.1 \mathrm{~m}$ phosphate buffer, $\mathrm{pH} 7.4$; and frozen. Cryostat midsagittal sections ( $10 \mu \mathrm{m}$ thick) of the vermis were prepared and immunostained for F3/F11 localization. The sections were washed in Tris buffer $(0.05 \mathrm{~m}$ Tris, $0.12 \mathrm{M} \mathrm{NaCl}$,
$\mathrm{pH} 7.4)$ and incubated with anti-F3 (1:300) antibody in Tris buffer containing $5 \% \mathrm{BSA}$ overnight at $4^{\circ} \mathrm{C}$. The sections were then washed with Tris buffer, flooded with goat anti-rabbit $\gamma$-globulin (1:50) for 30 $\mathrm{min}$, washed in Tris buffer, and flooded with peroxidase-antiperoxidase complex (PAP; 1:100) for $30 \mathrm{~min}$. After washing, sections were incubated with $0.05 \%$ diaminobenzidine (DAB) and $0.01 \% \mathrm{H}_{2} \mathrm{O}_{2}$ in Tris buffer for 10-15 min, washed, and mounted in Permount (Fisher Scientific Company). All observations on the cerebellar cortex were made around the primary fissure. The control sections incubated in nonimmune rabbit serum (1:300), goat anti-rabbit $\gamma$-globulin (1:50), and PAP complex (1:100) did not show any immunostaining.

Electron microscopy. Two-month- and 10-d-old mice were killed under ether anesthesia by intracardiac perfusion-fixation with about 50 $\mathrm{ml}$ of a solution containing $4 \%$ paraformaldehyde, $0.25 \%$ glutaraldehyde in $0.1 \mathrm{~m}$ phosphate buffer, $\mathrm{pH}$ 7.4. Their cerebella were removed and placed in fixative overnight. Vibratome sections $(50 \mu \mathrm{m}$ thick) were prepared and treated for F3 immunocytochemistry. The sections were washed in Tris buffer and incubated with anti-F3 (1:250) antibody in Tris buffer containing 5\% BSA for $48 \mathrm{hr}$ at $4^{\circ} \mathrm{C}$. The sections were then washed with Tris buffer and flooded with anti-rabbit $\gamma$-globulin Fab peroxidase (1:500) in Tris buffer, $5 \%$ BSA for $16 \mathrm{hr}$ at $4^{\circ} \mathrm{C}$. The sections were washed in Tris buffer and incubated for $15 \mathrm{~min}$ with $0.05 \%$ DAB and $0.01 \% \mathrm{H}_{2} \mathrm{O}_{2}$ in Tris buffer. The DAB-stained sections were fixed for $1 \mathrm{hr}$ at $4^{\circ} \mathrm{C}$ in $1 \%$ glutaraldehyde in phosphate buffer, $\mathrm{pH} 7.4$, postfixed for $20 \mathrm{~min}$ in $1 \%$ osmium tetroxide in phosphate buffer, dehydrated, and embedded in Epon. Ultrathin sections were cut and examined on a Hitachi electron microscope.

\section{Results}

\section{Light microscope immunocytochemistry of $F 3 / F 11$}

$\mathrm{F} 3 / \mathrm{F} 11$ has been shown to promote neurite outgrowth in vitro (Gennarini et al., 1991). In order to investigate whether the protein might be present at the right times and places to play a similar role in vivo, we studied F3/F11 expression during mouse cerebellar development using both the anti-D1-1 serum (Fig. 1) 


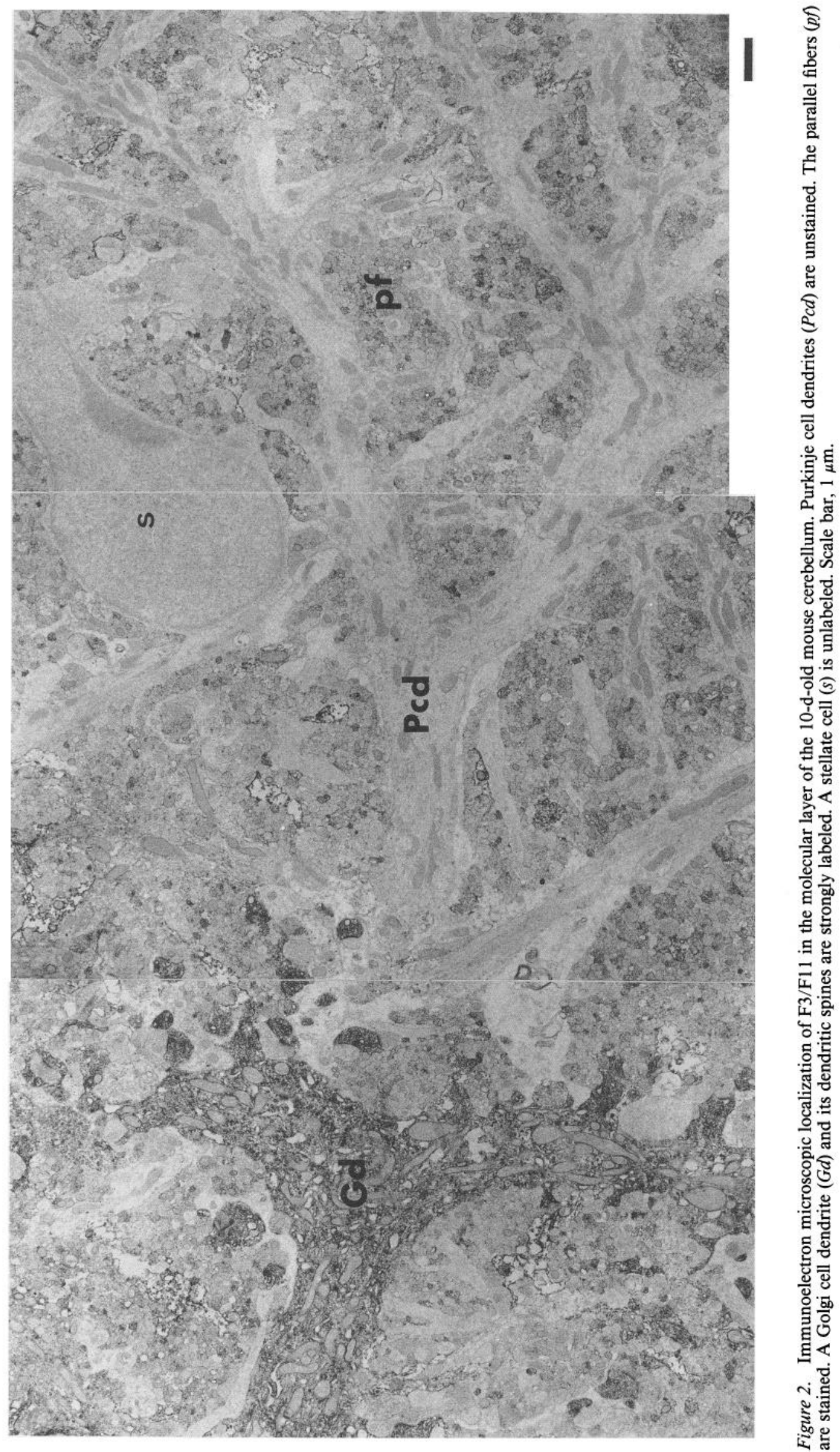



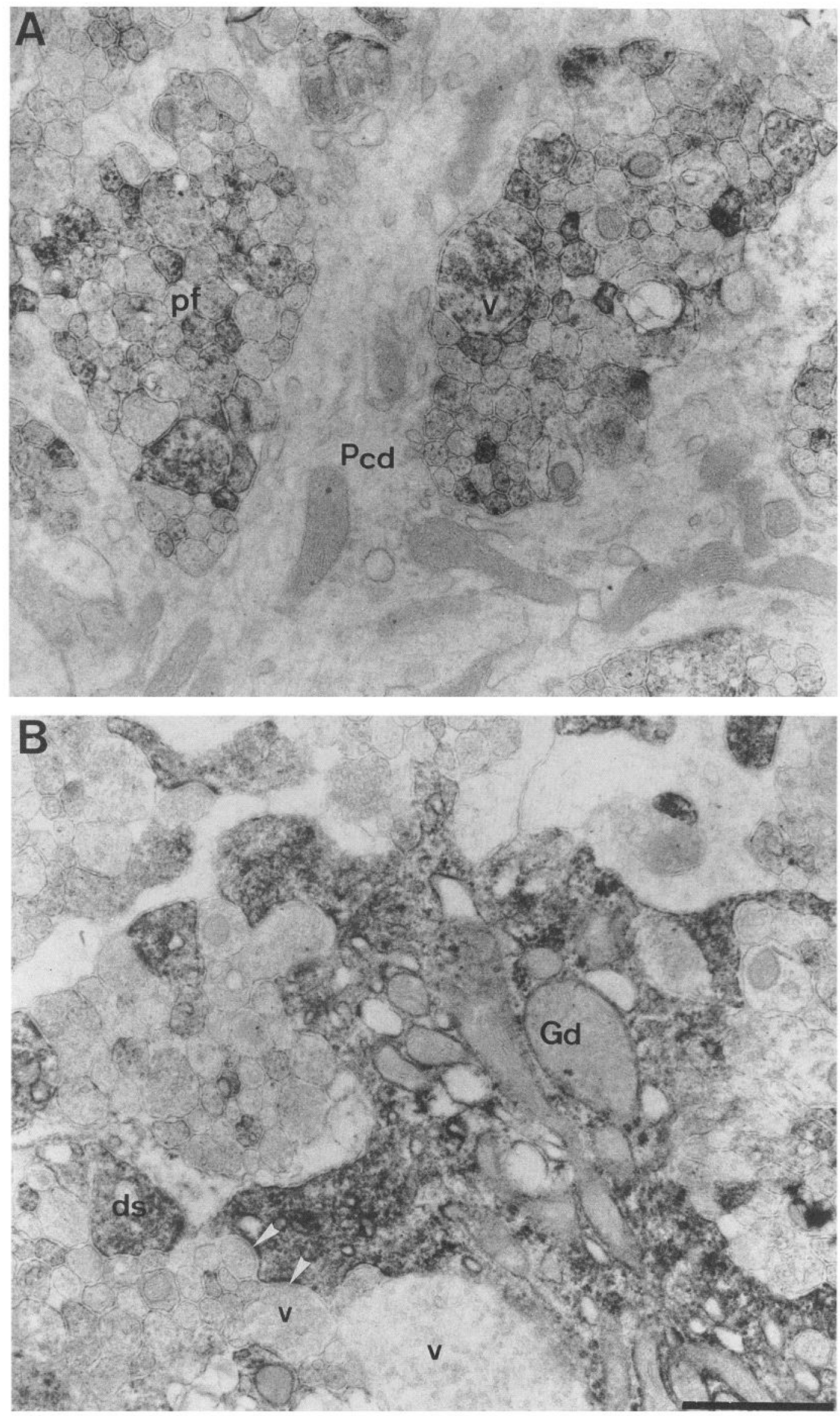
and the first-gencration anti-F3 scrum (not shown), which gave a similar pattern of immunoreactivity. At birth, when the layers of the cerebellar cortex are not yet well established, strong immunoreactivity for F3/F11 was observed on fibers in the molecular layer and in the internal region of the cerebellum. The neuroblasts of the external granular layer were devoid of staining (Fig. 1A). In the 5-d-old mouse cerebellum, the molecular layer displayed a punctate staining pattern suggesting that the parallel fibers, the granule cell axons, are heavily immunoreactive. Fibers in the white matter and in the internal granular layer were also immunoreactive, while the granule cell bodies both in the external and internal granular layers were unlabeled. The Purkinje cell bodies did not appear to express the antigen (Fig. 1B). On sections of 10-d-old cerebellum, the molecular layer was labeled, but with lower intensity than in the 5-d-old cerebellum (Fig. 1C). At both ages, the immunoreactivity was more intense in the uppermost region of the molecular layer, whcre immaturc parallel fibers are deposited just beneath the external germinative layer (Fig. 1B,C). This indicates that growing parallel fibers strongly express F3/F11. The Purkinje cell bodies and dendrites were unlabeled (Fig. 1C). A very similar expression pattern has been previously described for $\mathrm{F} 3$ in the cerebellum of 10-d-old mouse (Gennarini et al., 1989a) and for F11 in the embryonic chicken cerebellum (Rathjen et al., 1987).

\section{EM immunocytochemistry of F3/F11}

The distribution of the F3/F11 cell surface molecule was investigated in the cerebellar cortex from 10-d-old and adult mice at the EM level, using the first-generation anti-F3 serum. The age of $10 \mathrm{~d}$ was chosen because it corresponds to a period of intense neurite outgrowth and synaptogenesis. Midsagittal sections were observed in the region of the primary fissure. F3/ F11 was never detected in glial cells but was found to be present in discrete types of cerebellar neurons. In the labeled neuronal structures, immunoprecipitate was seen not only on the plasmalemma but also in the cytoplasm. Although we cannot exclude the possibility that an intracellular pool of F3/F11 molecules exists, this must be interpreted with caution. A shortcoming of preembedding immunostaining is that peroxidase precipitate diffuses variably within labeled structures and thus does not always allow accurate subcellular localization of the antigen (Piekut and Casey, 1983).

\section{Molecular layer}

In the molecular layer, the Purkinje cell dendrites were not immunoreactive at the two ages examined (see Figs. 2, 3A, 5A). The parallel fibers that mainly form synaptic junctions with the Purkinje cell dendrites were labeled including in their presynaptic varicosities (see Figs. $3 A ; 5 A, C$ ). Intcrestingly, the staining of the parallel fibers appeared to be heterogeneous within the same fascicle of axons both in 10-d-old and in adult animals. We cannot totally exclude the possibility that this may be an artifact due to variability in antibody penetration. If real, two hypotheses can be proposed to explain the heterogeneous distribution of F3/F11 in the parallel fibers. One possibility is that only a subpopulation of parallel fibers is immunoreactivc. Alternatively, F3/F11 expression within the same fiber could become stronger toward its distal end, a conclusion supported by the staining of the presynaptic varicosities. Thus, the observed heterogeneity may reflect different levels of the fiber sections relative to the synapse.

The Golgi cell dendrites, identified by their large size and low degree of branching, were immunoreactive for F3/F11 (Figs. 2, $3 B$ ). Their spines and postsynaptic densities were labeled while the presynaptic compartments contacting them never displayed any staining, either in 10-d-old or adult mice (Figs. $3 B, 4,5 B$ ). As can be seen in Figure 4, an axon, probably of a stellate cell, was devoid of staining, in contrast to several dendritic spines of a Golgi cell apposed to it (Fig. 4). Stellate cell bodies were also unlabeled as shown in Figure 2.

\section{Internal granular layer and white matter}

In the internal granular layer, the staining was restricted to some axonal processes. The granule cell bodies and their dendrites were unlabeled (Figs. 6,7A). Mossy fiber terminals that form part of a complex synaptic structure, the cerebellar glomerulus, contained F3/F11, whereas the dendritic spines of the granule cells connected to the mossy fiber did not (Fig. 6). The Golgi cell bodies identified on the basis of their eccentric and denticulate nucleus were immunoreactive for F3/F11 (Fig. 7A). Their axons contacting the unstained granule cell dendrites were also labeled (Fig. 7B). Several but not all of the myelinated axons in the white matter were labeled (not shown). The axons composing the white matter are the Purkinje cell axons and the climbing and mossy fibers. The mossy fibers that are labeled at their presynaptic terminals most probably contribute to the F3/ F11 immunoreactivity in the white matter.

Figure 8 provides a schematic view of the $F 3 / F 11$ expression pattern in the cerebellar cortex of the 10-d-old mice.

\section{Discussion}

F3/F1 1 is a neuronal cell surface glycoprotein that appears from in vitro assays to be involved in adhesive interactions between cells. Using the cerebellar cortex as a model, we have studied its localization during neural development. In keeping with previous results on cultured cells (Gennarini et al., 1989a), the protein was found exclusively on neurons. The cerebellar neurons were, however, not uniformly immunoreactive. Rather, F3/F11 showed a complex distribution pattern, being restricted to neuronal subpopulations and to particular subcellular compartments depending on the neuron type expressing it.

\section{The F3/F11 expression pattern is compatible with a role in process outgrowth and synaptogenesis}

As suggested by in vitro experiments (Chang et al., 1987; Gennarini et al., 1991), the promotion of neurite extension may be one of the functions of the F3/F11 protein. In the developing cerebellum, the parallel fibers were intensely immunoreactive, especially in the uppermost region of the molecular layer where the newly outgrowing fibers are deposited. This indicates that

\footnotetext{
Figure 3. Immunoelectron microscopic localization of F3/F11 in the molecular layer of the 10-d-old mouse cerebellum. Enlargement of two regions of Figure 2. $A$, Region of a Purkinje cell dendrite $(P c d)$. The parallel fibers $(p f)$ and their presynaptic varicosities $(v)$ are labeled. Note that the staining of the parallel fibers is heterogeneous within a fascicle of axons. $B$, Region of the Golgi cell dendrite (Gd) that is labeled, including in its dendritic spines $(d s)$ and at the postsynaptic densities (arrowheads). The presynaptic varicosities $(v)$ contacting them are unstained. Scale bar, $1 \mu \mathrm{m}$.
} 


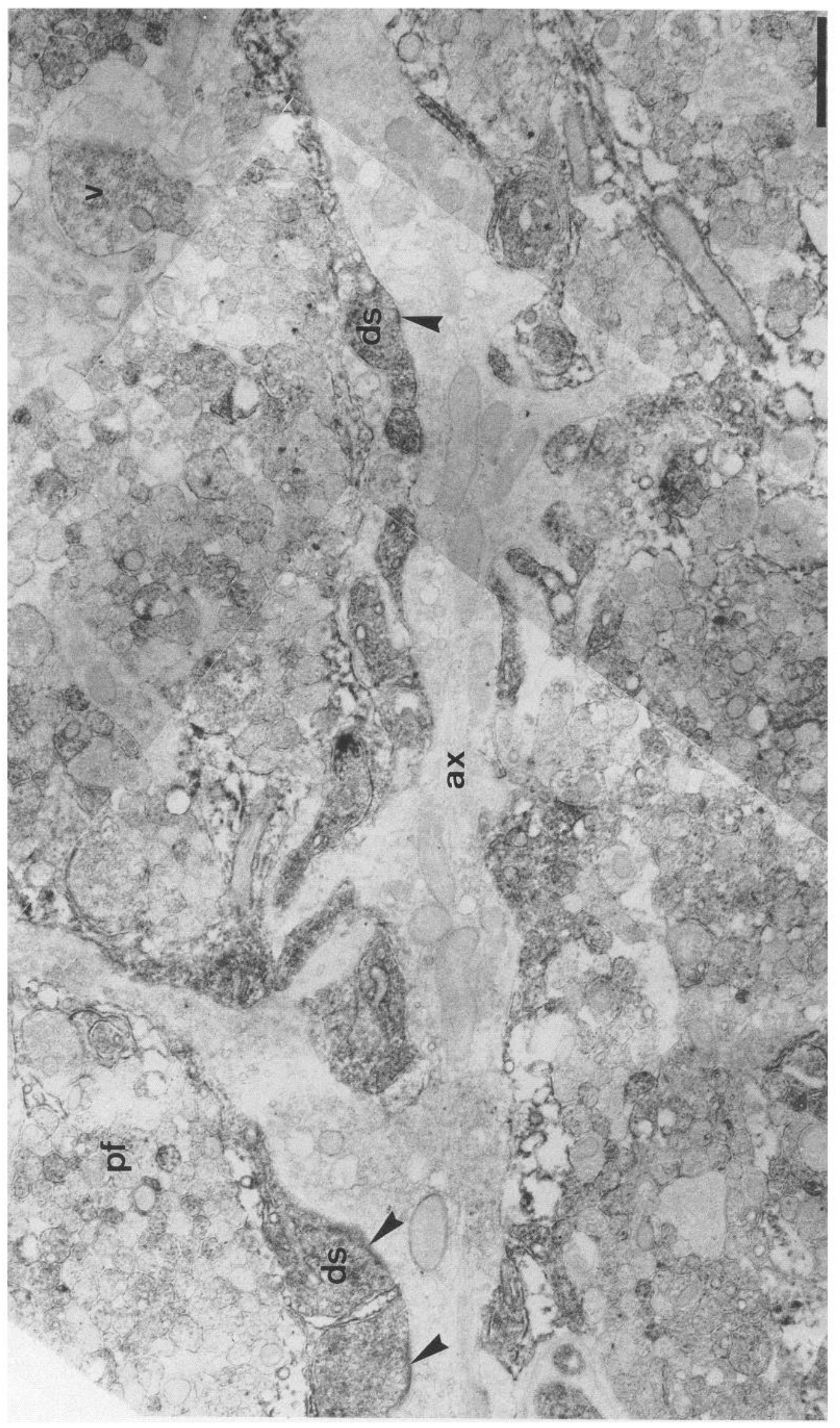

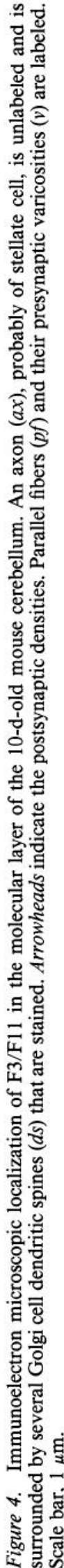



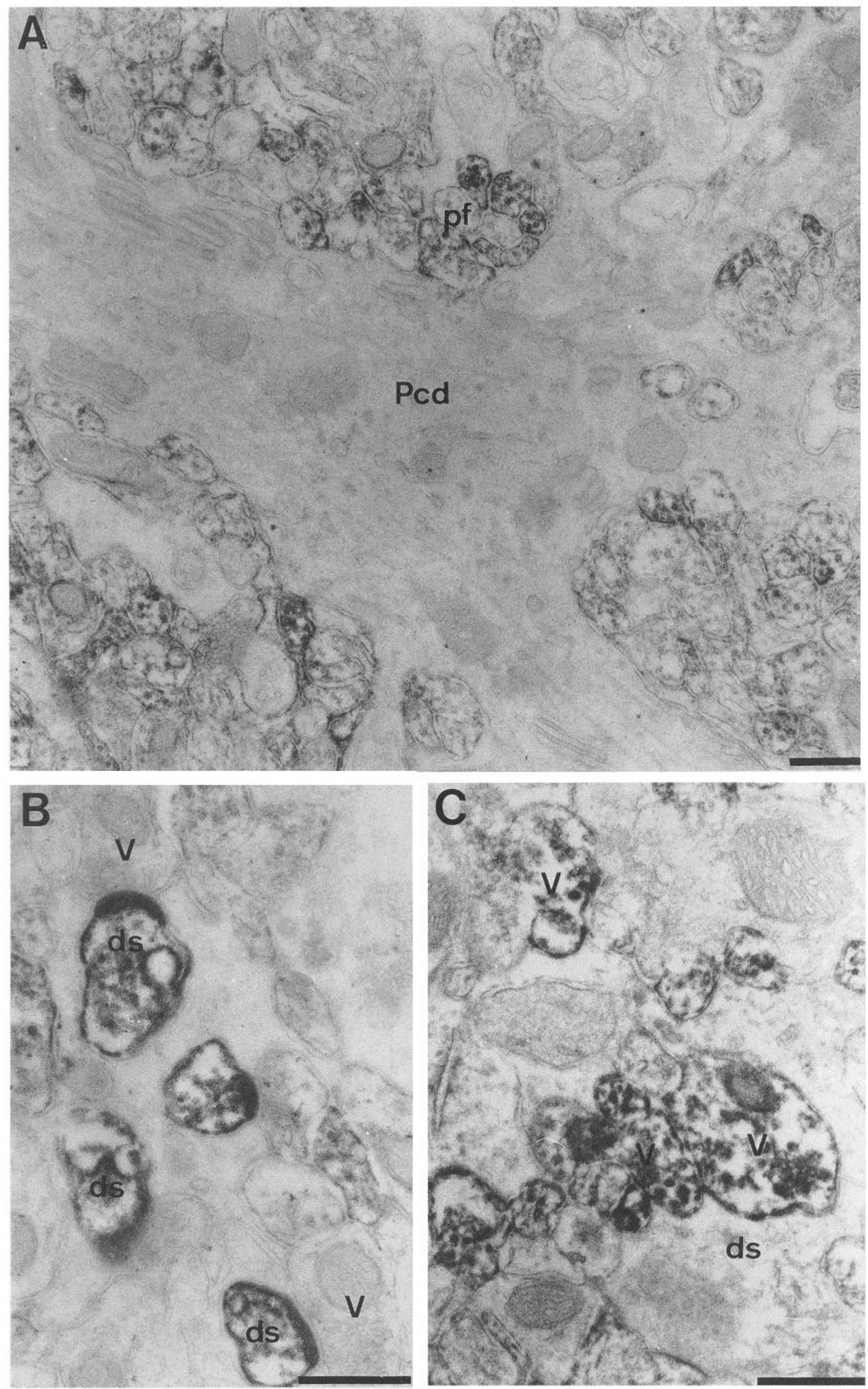

Figure 5. Immunoelectron microscopic localization of F3/F11 in the molecular layer of an adult mouse cerebellum. $A$, The Purkinje cell dendrite $(P c d)$ is unstained. Parallel fibers $(p f)$ are stained with heterogeneous intensity. $B$, Golgi dendritic spines $(d s)$ are stained, and the apposite presynaptic varicosities $(V)$ are not. $C$, Presynaptic varicosities $(V)$ of parallel fibers are immunoreactive whereas the Purkinje cell dendritic spines $(d s)$ they contact are not. Scale bar, $0.5 \mu \mathrm{m}$. 
Figure 6. Immunoelectron microscopic localization of F3/F11 in the internal granular layer of 10 -d-old mouse cerebellum. The granule cell body $(g c)$ and dendrites $(g)$ that are part of a cerebellar glomerulus are unstained. The mossy fiber terminal $(\mathrm{m} f)$ is immunoreactive. Scale bar, $1 \mu \mathrm{m}$.

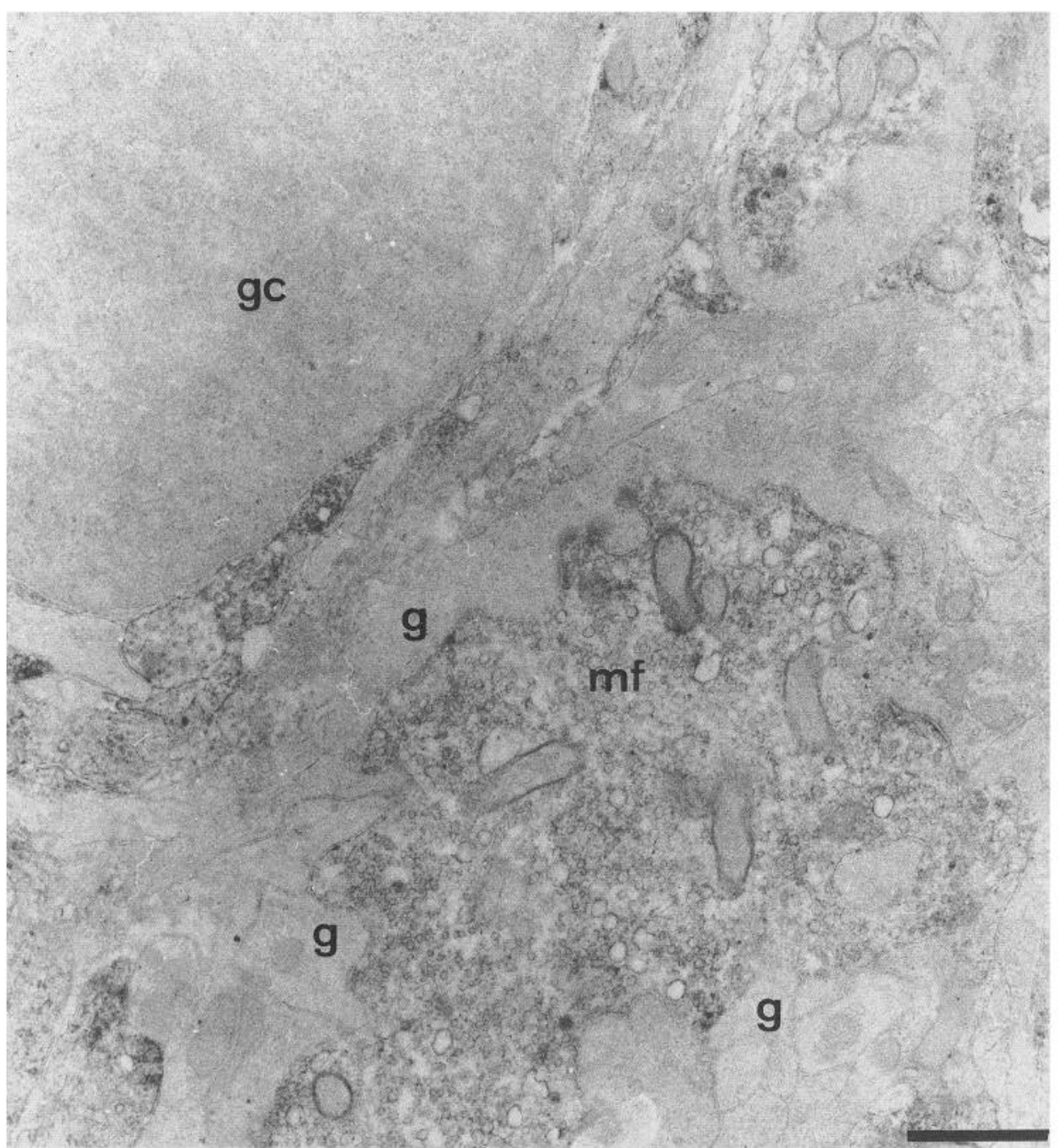

granule cell axons strongly express $\mathrm{F} 3 / \mathrm{F} 11$ as soon as they begin to grow and that expression is stronger on growing fibers. It is noticeable that the parallel fiber immunostaining was very intense in 5-d-old cerebellum and appeared to decrease thereafter. Hence, the protein is present at the right times and places to take part in neurite growth and guidance in vivo.

In 10-d-old and adult cerebella, the granule cell bodies and dendrites were not immunoreactive whereas their axons were labeled with different intensities. One likely interpretation of the strikingly different labeling intensities of parallel fibers within a given fascicle would be that $\mathrm{F} 3 / \mathrm{F} 11$ is preferentially distributed in distal regions of the axons, implying a function in guiding the axons toward their target site. It is, however, equally possible that, for reasons that are not obvious, subsets of parallel fibers express different amounts of the antigen. Both in the developing and adult cerebellum, F3/F11 immunoreactivity was present at synaptic sites of three types: the presynaptic varicosities of the parallel fibers, the dendritic spines of the Golgi cells, and the mossy fiber terminals. From this it may be inferred that F3/F11 is involved in the formation and/or maintenance of functional synapses. Conceivably, the protein may play a role in both axonal growth and synaptogenesis depending on its precise spatial and temporal expression patterns.

\section{Polarized distribution of F3/F11 at synapses suggests involvement in heterophilic interactions}

Although F3/F11 may be expressed pre- or postsynaptically, it was never observed to be coexpressed at pre- and postsynaptic sites that were in contact. In the molecular layer, the protein was present presynaptically in the parallel fibers and their varicosities and postsynaptically in the Golgi cell dendrites and dendritic spines. However, the main postsynaptic compartment in contact with the parallel fibers, the dendritic arborization of the Purkinje cells, was not immunoreactive, nor were the presynaptic fibers contacting immunostained Golgi cell dendrites ever found to be labeled. In the internal granular layer, F3/F11 was expressed on the mossy fiber terminals, which provide input to the synaptic complex termed cerebellar glomerulus, but not on the granule cell dendrites that are contacted by them. These observations indicate that F3/F11 may be engaged in heterophilic interactions at synaptic sites, in contrast with what has been reported for N-CAM (Rutishauser and Goridis, 1986) and L1 (Lemmon et al., 1989). The conclusion that F3/F11-mediated adhesion is heterophilic is corroborated by data on F3/ F11-expressing $\mathrm{CHO}$ transfectants. We previously showed (Gennarini et al., 1991) that the F3-expressing transfectants 

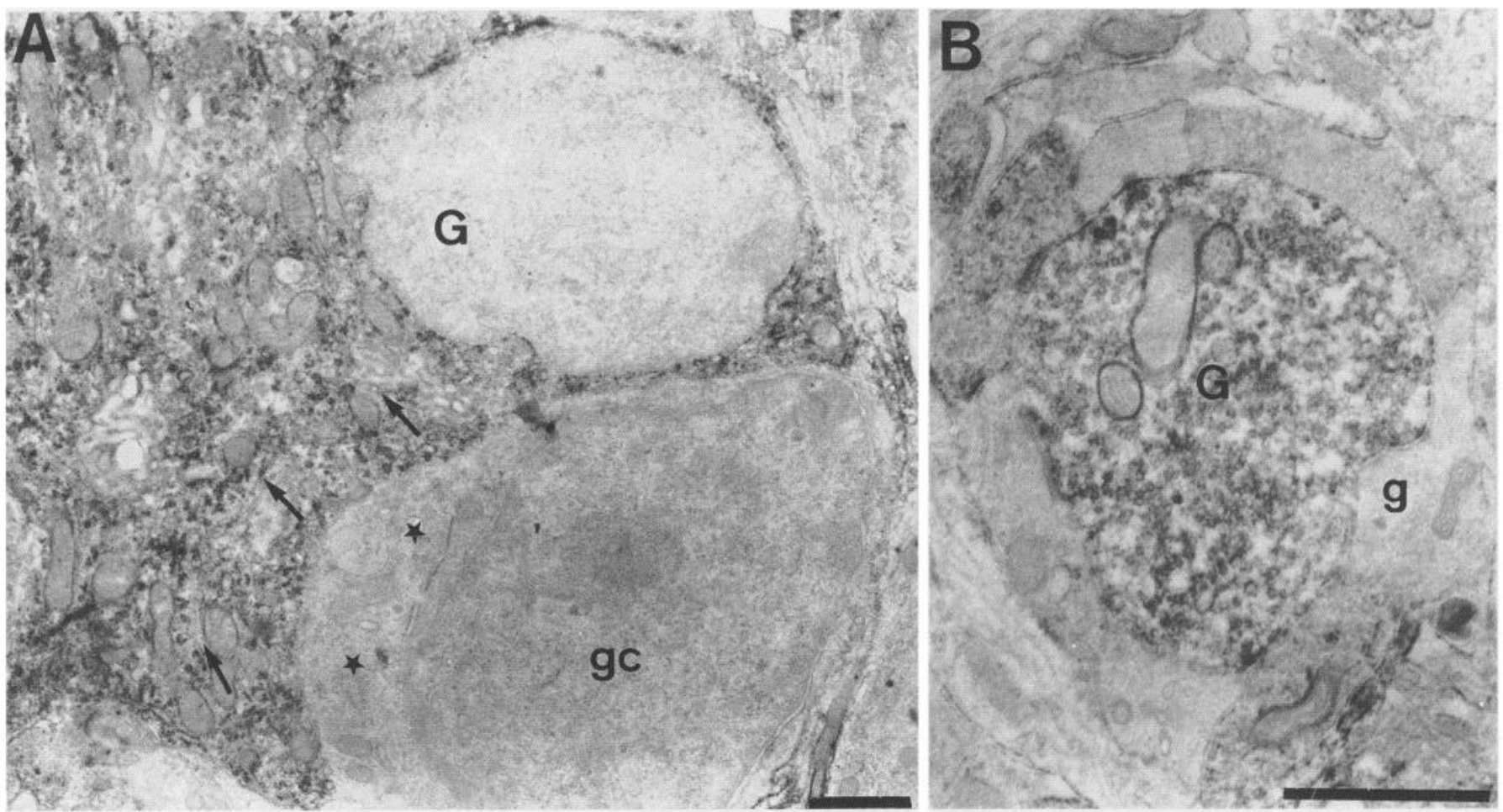

Figure 7. Immunoelectron microscopic localization of F3/F11 in the internal granular layer of 10-d-old mouse cerebellum. A, A Golgi cell body $(G)$ is labeled. Arrows point to the cytoplasm of the Golgi cell. A granule cell body $(g c)$ is unstained. The cytoplasm of the granule cell is indicated with stars. $B$, A Golgi cell axon $(G)$ is immunoreactive whereas the granule cell dendrites $(g)$ in contact are not. Scale bar, $1 \mu \mathrm{m}$.

exhibited enhanced self-adhesive properties but that they were also able to form mixed aggregates with parental nontransfected cells. It is therefore likely that $\mathrm{CHO}$ cells express a still unidentified ligand with which F3 is able to interact.

Several hypotheses could be proposed to explain how such a heterophilic interaction could play a role in synaptic formation. Selective affinity may occur between F3/F11 and a specific albeit still unknown ligand. Such an interaction could, for instance, participate in synaptic formation between parallel fibers and Purkinje cell dendrites. However, one should also consider the possibility that F3/F11 may mediate homophilic interactions, inducing an avoidance mechanism thus leading to suppression of synapse formation between processes that are both $\mathrm{F} 3 / \mathrm{F} 11$ positive. For example, positive presynaptic varicosities of parallel fibers would never contact a positive Golgi cell dendrite. More generally, this might also explain why the apposition between two presynaptic terminals is precluded. Precedent exists in this domain, and it is interesting to note that directional inhibition of axon growth is becoming recognized as a mechanism of fundamental importance during neural development (reviewed in Patterson, 1988). At least in one case, it has been clearly related to the presence of GPI-anchored molecules (Walter et al., 1990).

\section{Comparison with structurally similar neuronal surface proteins}

The closely related rat protein TAG-1 is transiently expressed in the cerebellum and is located on the premigratory cells of the external granular layer (Yamamóto et al., 1986; Furley et al., 1990). It is therefore very interesting to note that in spite of strong similarities in their structure, the TAG-1 and F3/F11 molecules are differentially expressed during cerebellar devel- opment. The determined temporal and spatial expression of these neuronal cell surface molecules thus indicates that they may not serve similar functions during neuronal morphogenesis.

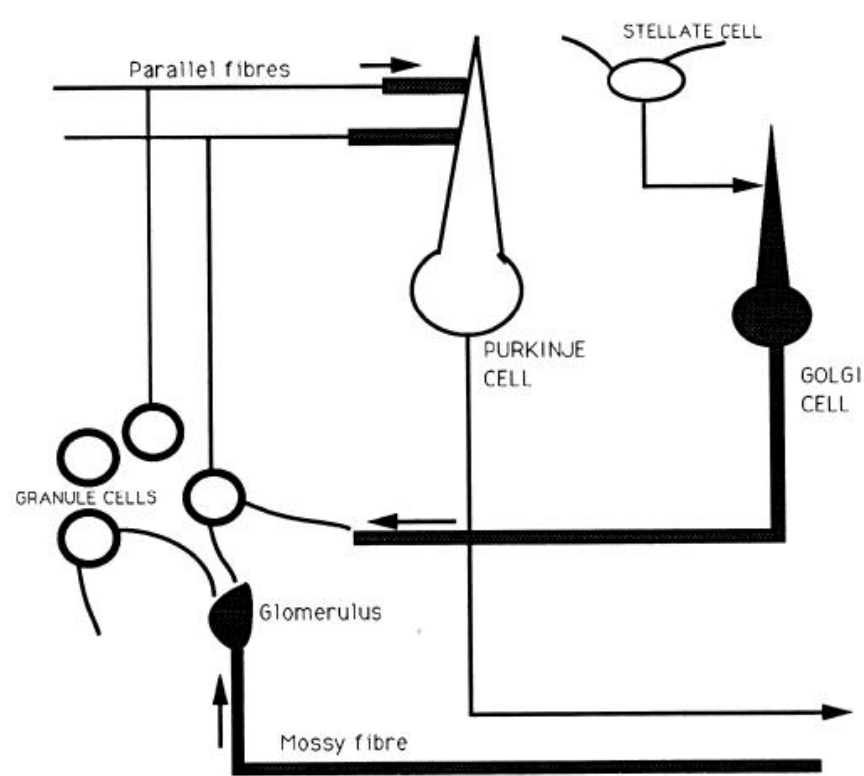

Figure 8. Immunoreactivity for F3/F11 in circuitry of the cerebellar cortex. For neuronal structures positively identified, shaded regions represent F3 immunoreactivity. Note that F3/F11 was never observed to be coexpressed in the pre- and postsynaptic sites that were in contact and that it is polarized to axons in the granule cells but not the Golgi cells. 
A comparison between the respective distributions of F3/F11 and L1, whose extracellular domains share with F3 the same overall structure and around $25 \%$ sequence identity (Moos et al., 1988; Gennarini et al., 1989b), is more revealing. L1 mediates neuron-neuron adhesion via a homophilic binding mechanism (Lemmon et al., 1989; Kadmon et al., 1990) and plays a prominent role in the fasciculation of neurons (Fischer et al., 1986). In the cerebellum, L1 is much more abundant on the parallel fibers than on the corresponding granule cell bodies (Pershon and Schachner, 1987). In contrast to F3/F11, however, $\mathrm{L} 1$ is not present on the presynaptic membrane of the parallel fiber varicosities and may therefore not be involved in the formation and maintenance of synapses (Pershon and Schachner, 1987). In order to approach their appropriate target sites, that is, the Purkinje cell dendritic spines, individual parallel fibers have to deviate from the fascicle, and we may assume that they lose L1 in the course of this process while, as argued above, F3/ F11 expression may even become stronger. Hence, these two neuronal adhesion molecules may be quite complementary in terms of both their spatial distribution and their functional role during cerebellar morphogenesis.

Generally speaking, L1 is found at contact sites between surface membranes that both express the molecule whereas quite the opposite is true for F3/F11. Only in the parallel fiber fascicles did we find two apposing labeled axons, but due to the heterogeneity in parallel fiber immunoreactivity, this was the exception rather than the rule. Conceivably, this difference between the respective localizations of the two molecules reflects differences in their mechanism of action, $\mathrm{Ll}$ being involved in homophilic adhesion, F3/F11 mediating heterophilic interactions or favoring contacts between surface membranes of which only one bears the protein.

\section{F3/F11 expression is polarized to the axon within granule but not within Golgi cells}

In the granule cell, F3/F11 immunoreactivity was confined to the axonal compartment while the cell bodies and dendrites were devoid of labeling. By contrast, F3/F11 was present in all parts of the Golgi interneurons. On the basis of the observation that Thy1, a glypiated molecule of the Ig superfamily, has an exclusively axonal localization in long-term cultured hippocampal neurons, Dotti et al. (1991) proposed that glypiated molecules are preferentially sorted to the axonal compartment. This may be a potent way for the neuron to express cell adhesion molecules differentially in axons and dendrites. As Thyl itself has been found to be present on the dendrites of hippocampal pyramidal neurons and cerebellar Purkinje cells in tissue sections (Morris et al., 1985; Xue et al., 1990), the preferential delivery of glypiated membrane proteins to axons may apply only to certain types of neurons or may even not occur at all in vivo.

We deem it extremely unlikely that Golgi cells express a special isoform of F3/F11 that contains a transmembrane segment since only one gene is present in the mouse genome and since, despite intensive effort, we have found no indication for alternative splicing of the pre-mRNA (Gennarini et al., 1989a; G. Gennarini and C. Goridis, unpublished observations). If we exclude this possibility, our results clearly indicate that a glycolipid-anchored protein can show a polarized localization to the axonal compartment in one type of neuron, and a uniform distribution in another. In this case, Golgi cells, which are local circuit interneurons, would lack the sorting mechanism respon- sible for the targeting of glypiated proteins to the axonal compartment. It will be interesting to learn whether other glypiated proteins share the same spatial distribution in the two types of neurons. The polar distribution of the GPI-anchored molecules seems to depend on the neuron type expressing them and/or on environmental cues created by the cellular environment in the brain. When the stabilization of neuronal polarity takes place and how the segregation of F3/F11 in the plasma membrane is maintained on granule cells are not clear. In this context, one might propose that the molecular machinery responsible for generating and maintaining neuronal polarity could be triggered by synaptogensis or immediately precede it.

\section{References}

Altman J (1972a) Postnatal development of the cerebellar cortex in the rat. II. Phases in maturation of Purkinje cells and of the molecular layer. J Comp Neurol 145:399-464.

Altman J (1972b) Postnatal development of the cerebellar cortex in the rat. III. Maturation of the components of the granular layer. J Comp Neurol 145:465-514.

Brümmendorf T, Wolff MJ, Frank R, Rathjen FG (1989) Neural cell recognition molecule $\mathrm{F} 11$ : homology with fibronectin type III and immunoglobulin type $C$ domains. Neuron 2:1351-1361.

Chang S, Rathjen FG, Raper JA (1987) Extension of neurites on axons is impaired by antibodies against specific neural cell surface glycoproteins. J Cell Biol 104:355-362.

Chow I (1990) Cell-cell interaction during synaptogenesis. J Physiol (Paris) 84:121-127.

Dodd J, Morton SB, Karagogeos D, Yamamoto M, Jessel TM (1988) Spatial regulation of axonal glycoprotein expression on subsets of embryonic spinal neurons. Neuron 1:105-116.

Doherty P, Walsh FS (1989) Neurite guidance molecules. Curr Opin Cell Biol 1:1102-1106.

Dotti CG, Parton RG, Simmons K (1991) Polarized sorting of glypiated proteins in hippocampal neurons. Nature 349:158-161.

Edelman GM (1984) Cell-surface modulation and marker multiplicity in neural patterning. Trends Neurosci 7:78-84.

Edelman GM (1986) Cell adhesion molecules in neural histogenesis. Annu Rev Physiol 48:417-430.

Fischer G, Kunemund V, Schachner M (1986) Neurite outgrowth patterns in cerebellar microexplant cultures are affected by antibodies to the cell surface glycoprotein L1. J Neurosci 6:605-612.

Furley AJ, Morton SB, Manalo D, Karagogeos D, Dodd J, Jessel TM (1990) The axonal glycoprotein TAG-1 is an immunoglobulin superfamily member with neurite outgrowth-promoting activity. Cell 61:157-170.

Gennarini G, Rougon G, Vitiello F, Corsi P, Di Benedetta C, Goridis $C$ (1989a) Identification and cDNA cloning of a new member of the L2/HNK-1 family of neural surface glycoproteins. J Neurosci Res 22:1-12.

Gennarini G, Cibelli G, Rougon G, Mattei MG, Goridis C (1989b) The mouse neuronal cell surface protein F3: a phosphatidylinositolanchored member of the immunoglobulin superfamily related to chicken contactin. J Cell Biol 109:775-788.

Gennarini G, Rougon G, Goridis C (1990) F3: a new developmentally regulated member of the HNK-1 family. Acta Histochem [Suppl] 38: $65-69$.

Gennarini G, Durbec P, Boned A, Rougon G, Goridis C (1991) Transfected F3/F11 neuronal cell surface protein mediates intercellular adhesion and promotes neurite outgrowth. Neuron 6:595-606.

He HT, Naquet P, Caillol D, Pierres M (1991) Thy-1 supports adhesion of mouse thymocytes to thymic epithelial cells through a $\mathrm{Ca}^{++}$ independent mechanism. $J$ Exp Med, in press.

Kadmon G, Kowitz A, Altevoght P, Schachner M (1990) The neural cell adhesion molecule NCAM enhances L1-dependent cell-cell interactions. J Cell Biol 110:193-208.

Keilhauer G, Faissner A, Schachner M (1985) Differential inhibition of neuron-neuron, neuron-astrocyte and astrocyte-astrocyte adhesion by L1, L2 and N-CAM antibodies. Nature 316:728-730.

Künemund V, Jungalwala FB, Fischer G, Chou DKH, Keilhauer G, Schachner M (1988) The L2/HNK-1 carbohydrate of neural cell 
adhesion molecule is involved in cell interactions. J Cell Biol 106: 213-223.

Lemmon V, Farr KL, Lagenaur C (1989) Ll-mediated axon outgrowth occurs via a homophilic binding mechanism. Neuron 2:1597-1603.

Moos M, Tacke R, Scherer H, Teplow D, Fruh K, Schachner M (1988) Neural adhesion molecule $\mathrm{Ll}$ as a member of the immunoglobulin superfamily with binding domains similar to fibronectin. Nature 334: 701-703.

Morris RJ, Beech JN, Barber PC, Raisman G (1985) Early stage of Purkinje cell maturation demonstrated by Thy-1 immunohistochemistry on postnatal rat cerebellum. J Neurocytol 14:427-452.

Palay SL, Chan-Palay V, eds (1974) Cerebellar cortex, cytology and organization. New York: Springer.

Patterson PH (1988) On the importance of being inhibited or saying no to the growth cones. Neuron 1:263-267.

Persohn E, Schachner M (1987) Immunoelectron microscopic localization of the neural cell adhesion molecules $\mathrm{Ll}$ and N-CAM during postnatal development of the mouse cerebellum. J Cell Biol 105:569576.

Piekut DT, Casey SM (1983) Penetration of immunoreagents in vibratome-sectioned brain: a light and electron microscopic study. $\mathrm{J}$ Histochem Cytochem 31:669-674.
Rathjen FG, Wolff JM, Frank R, Bonhoeffer F, Rutishauser U (1987) Membrane glycoproteins involved in neurite fasciculation. J Cell Biol 104:343-353.

Riopelle RJ, McGarry RC, Roder JC (1986) Adhesion properties of a neuronal epitope recognized by the monoclonal antibody HNK-1. Brain Res 367:20-25.

Rutishauser U, Goridis C (1986) N-CAM: the molecule and its genetics. Trends Genet 2:72-76.

Rutishauser U, Jessel TM (1988) Cell adhesion molecules in vertebrate neural development. Physiol Rev 68:819-857.

Walter J, Müller B, Bonhoeffer F (1990) Axonal guidance by an avoidance mechanism. J Physiol (Paris) 84:104-110.

Williams AF, Barclay AN (1988) The immunoglobulin superfamily: domains for cell surface recognition. Annu Rev Immunol 6:381-405.

Xue GP, Calvert RA, Morris RJ (1990) Expression of the neuronal cell surface glycoprotein Thy-1 is under post-transcriptional control, and is spatially regulated, in the developing olfactory system. Development 109:851-864.

Yamamoto M, Boyer AM, Crandall JE, Edwards M, Tanaka H (1986) Distribution of stage-specific neurite-associated proteins in the developing murine nervous system recognized by a monoclonal antibody. J Neurosci 6:3576-3594. 